\title{
The family needs of patients admitted to the intensive care unit - a preliminary report
}

\section{Potrzeby członków rodzin chorych leczonych na oddziale intensywnej terapii - doniesienia wstępne}

\author{
Katarzyna Białek \\ Institute of Medical Sciences, Faculty of Medicine and Health Sciences, Collegium Medicum, Jan Kochanowski University, Kielce, \\ Poland \\ Head of the Institute: Beata Kręcisz MD, PhD, Prof. JKU
}

Key words: intensive care unit, family needs, patient's family, hospitalization.

Słowa kluczowe: oddział intensywnej terapii, potrzeby rodzin, rodzina chorego, hospitalizacja.

\begin{abstract}
Introduction: Admission of a family member to an intensive care unit (ICU) is deeply distressing. Families of critically ill patients have needs that should be recognized and met by the ICU medical staff. Many investigations have presented that meeting the needs of families may help them cope with the stress and improve their well-being during the hospitalisation. Aim of the research: To identify the needs of family members of patients admitted to the ICU, where patients in a condition threatening their health and life are treated.

Material and methods: Completed questionnaires were obtained from 37 family members of patients treated at a cardiac intensive care and intensive care unit, to identify the needs of family members of patients admitted to ICUs; the author's questionnaire was used. The questionnaire included a list of 16 needs that the relatives assessed on a scale from 1 to 4 . The higher the number, the more important the need is in the subjective perception of the relatives.

Results and conclusions: The most frequently endorsed stressors in family members of ICU patients were as follows: direct threat to the patient's life, poor prognosis, altered appearance of the patient, and the way the family will function after the end of hospitalization. Needs such as truthful information provided by physicians at least once a day, instructions from the physicians about how to deal with the patient after leaving the hospital, and confidence that the patient is receiving the best possible care were considered to be the most important. Meeting these needs should be a primary responsibility of ICU medical staff.
\end{abstract}

\section{Streszczenie}

Wprowadzenie: Przyjęcie członka rodziny na oddział intensywnej terapii (OIT) może być bardzo stresujące. Rodziny pacjentów w stanie krytycznym mają potrzeby, które powinien rozpoznać i zaspokoić personel medyczny OIT. W badaniach wykazano, że zaspokojenie potrzeb krewnych może pomóc im radzić sobie ze stresem i ułatwić adaptację do hospitalizacji. Cel pracy: Rozpoznanie potrzeb członków rodzin pacjentów przyjętych na OIT, gdzie leczeni są w stanie zagrażającym ich zdrowiu i życiu.

Materiał i metody: Wypełnione ankiety otrzymano od 37 członków rodzin pacjentów leczonych na oddziałach intensywnej terapii i intensywnej terapii kardiologicznej. W celu zidentyfikowania potrzeb członków rodzin pacjentów przyjętych na OIT wykorzystano kwestionariusz autorski. Kwestionariusz zawierał listę 16 potrzeb, które krewni oceniali w skali od 1 do 4 . Im wyższa była liczba, tym ważniejsza jest potrzeba w subiektywnym postrzeganiu bliskich.

Wyniki i wnioski: Najczęściej występującymi czynnikami stresogennymi u członków rodzin chorych leczonych na OIT były: bezpośrednie zagrożenie życia chorego, złe rokowanie, zmieniony wygląd chorego oraz to, jak będzie funkcjonować rodzina po zakończeniu hospitalizacji. Za najważniejsze uznano potrzeby, takie jak przekazywanie przez lekarzy informacji zgodnie z prawdą przynajmniej raz dziennie, wskazówki dotyczące postępowania z chorym po wyjściu ze szpitala i pewność, że pacjent otrzymuje najlepszą możliwą opiekę. O funkcjonowanie rodziny po zakończeniu hospitalizacji najbardziej obawiali się współmałżonkowie lub partnerzy leczonych chorych i tych wspólnie mieszkających z chorym. Dostęp do informacji na temat stanu zdrowia pacjenta i jakości relacji z personelem medycznym to priorytetowe potrzeby członków rodzin, a ich zaspokojenie powinno być głównym obowiązkiem personelu medycznego OIT. 


\section{Introduction}

When a seriously ill person is admitted to an intensive care unit (ICU) this fact affects not only the ill person but also their entire family. The clinical condition of ICU patients causes anxiety and stress not only with regard to their health, but also the course of the therapeutic process, prognosis, family functioning after the end of hospitalisation, and the possible loss of a loved one [1, 2]. Moreover, the stress related to the stay of a relative at an ICU may affect how family members cope with their disease, thus hindering the support process that they need [3].

Many ICU patients are unable to communicate with medical staff or participate in making decisions related to the treatment. This could stem from the severity of the disease or sedation. Hence, medical staff increasingly turn to family members to obtain their consent on key decisions related to taking therapeutic measures. Proper communication with the patient's family is therefore essential to ensure full provision of patient-centred care. Increasingly, a holistic approach to care is emphasised and more attention is paid not only to the needs of the treated patients, but also to their relatives. By analysing the needs of the families of people hospitalised at ICUs, it was demonstrated that they most often expected information about the health condition and treatment of their relatives, as well as the prognosis, potential complications, information about further procedures after discharge from the hospital, and certainty that the patient will receive the best possible care [4-8]. Satisfying their needs is also important for the sake of facilitating the adaptation of the family to a new situation. Moreover, if these needs are not identified and understood, the family members are exposed to stronger feelings of stress, anxiety, and depression [9].

Family members are an integral part of the healthcare process at an ICU. For these reasons, the measurement of its quality should also take into account the perspective of the relatives of the treated patients and the identification and analysis of their needs.

\section{Aim of the research}

The aim of the study was to assess the needs of the families of patients treated in intensive cardiac care units as well as in anaesthesiology and intensive care units, where patients in a condition threatening their health and life are treated.

\section{Material and methods}

The research was conducted among family members of patients treated at a cardiac intensive care unit and the Department of Anaesthesiology and Intensive Care of the Provincial Hospital in Kielce during the period from November 2019 to February 2020. Both the admissions and treatment of patients in these de- partments are focused on diseases of the heart and circulatory system as well as respiratory system. All patients were admitted in an emergency mode in a life- and health-threatening condition.

The Bioethics Committee of Jan Kochanowski University approved the study (25/2020). Due to the announcement of the SARS-CoV-2 pandemic and the introduction of the visit ban, the study was conducted on only 37 people.

The original questionnaire used for the study consisted of 2 parts. The first one contained 9 questions referring to demographic data, such as gender, age, education, marital status, degree of kinship, joint residence with the patient, number of hospitalisations at an ICU, day of hospitalisation, and distance from the place of residence to the hospital, and a multiplechoice question about the most stressful factors during the stay of a family member at an ICU. The second part of the questionnaire included a list of 16 needs based on previous interviews with the medical staff of the departments and a literature review. The relatives assessed their needs on a scale from 1 to 4 by responding to the request: "Please write down how important each of the following needs are for you during the stay of a family member at an ICU by marking the appropriate number: not important (1), not very important (2), important (3), very important (4)”. The higher the number, the more important the need is in the subjective perception of the respondent. The respondents completed questionnaires at the ward during the patient visiting hours. The purpose of the study was explained to all respondents, and they were informed that the participation is voluntary and serves only scientific purposes.

\section{Statistical analysis}

The analysis of quantitative variables (i.e. ones expressed in numbers) was performed by calculating the mean, standard deviation, median, quartiles, minimum, and maximum. The analysis of qualitative variables (i.e. ones not expressed in numbers) was performed by calculating the number and percentage of the occurrences of each value. The comparison of the values of qualitative variables in the groups was conducted by using the $\chi^{2}$ test (with the Yates's correction for $2 \times 2$ tables) or Fisher's exact test when low expected numbers appeared in the tables. The comparison of the values of quantitative variables in 2 groups was performed using the Mann-Whitney test. The comparison of the values of quantitative variables in 3 or more groups was performed using the Kruskal-Wallis test. After detecting statistically significant differences, post-hoc analysis using Dunn's test was conducted to identify groups with statistically significantly differences. The correlations between quantitative variables were analysed using the Spearman correlation coefficient. 
A significance level of 0.05 was adopted in the analysis. The analysis was carried out using the R software package, version 4.0.2 [10].

\section{Results}

\section{Sociodemographic characteristics of the study participants}

Completed questionnaires were obtained from $37 \mathrm{fa}$ mily members of patients treated at a cardiac intensive care and intensive care unit, including 23 (62.16\%) women and $14(37.84 \%)$ men aged 19 to 65 years $(\mathrm{SD}=11.93 \%)$. The study group was dominated by people with secondary education $(N=17), 14$ people had university education $(N=37.84 \%)$, and the rest possessed a level of education below secondary. Thrityfour out of the 37 relatives of treated patients (91.81\%) were married and/or in an informal partnership, and $3(8.11 \%)$ respondents were not in a relationship. Among the respondents, the most populous group was formed by the children of the treated patients $(N=22)$, followed by spouses and/or partners $(27.03 \%)$ grandchildren $(8.11 \%)$, siblings $(2.70 \%)$, and other persons $(2.70 \%)$. The average age of a patient was 69.05 \pm 11.06 years and ranged from 43 to 87 years. The majority (54.05\%) of the respondents did not live with the patient. Considering the number of hospitalisations of the ICU patient, most respondents answered that it was the first hospitalisation (62.16\%), 4 - the second one (10.81\%), 7 - the third one (18.92\%), and 2 - the fourth one $(5.41 \%)$. Only in one case was the patient hospitalised 5 times $(2.70 \%)$. The research was conducted after an average of $4.35 \pm 4.53$ days of hospitalisation. The duration of the patient's hospitalisation ranged from 1 to 23 days at an ICU. Most of the surveyed relatives lived in the city where the hospital was located $(N=17)$, 7 lived within a distance of $20 \mathrm{~km}$ (18.92\%), and the rest lived more than $20 \mathrm{~km}$ away.
The most frequently endorsed stressful factors in family members of ICU patients

It was noted that the most frequently mentioned stress factors in the family members of ICU patients were as follows: direct threat to the patient's life (89.19\%), poor prognosis (62.16\%), altered appearance of the patient $(56.76 \%)$, and the way the family will function after the end of hospitalisation (45.95\%). The numerical values of all factors are presented in Table 1 .

The answer "Thinking of the way the family will function after the end of the hospitalisation" was mostly indicated by people caring for their spouse or partner, and least often by people caring for other people $(p<0.001)$ (Table 2$)$. This answer was also more often selected in the group of people living with the patient $(p=0.015)$. $P$-values below 0.05 also show significant differences between groups in terms of the distance from the hospital. The greater the distance the respondents had to travel from their place of residence to the hospital $(p=0.004)$ the more often the answer "Commuting to the hospital" was given. The patient's age also proved to be significant. The answer "Poor prognosis" was most often found in the group of people over 70 years old, and the least frequently in the group of 66-70-year-olds ( $p=0.04$ ).

Gender, age, education, marital status, number of hospitalizations at an ICU, and the day of hospitalization were not related to the most stressful factors selected by relatives.

\section{Most and least important needs of the family members of ICU patients}

Family members rated their needs on a scale from 1 to 4 . Higher numbers meant more important and vital needs. The following were considered to be the most important: providing truthful information by doctors (in accordance with the actual state

Table 1. The most frequently endorsed stressful factors in family members of intensive care unit patients

\begin{tabular}{|lcc|}
\hline The most frequently endorsed stressful factors in family members of ICU patients & $n$ & $\%$ \\
Direct threat to the patient's life & 33 & 89.19 \\
Poor prognosis & 23 & 62.16 \\
Lack of communication with medical staff and not to provide information about the patient's condition & 7 & 18.92 \\
Altered appearance of the patient & 21 & 56.76 \\
How the family will function after the end of hospitalisation & 17 & 45.95 \\
Relationship between family members and medical staff & 5 & 13.51 \\
Healthcare bureaucracy & 2 & 5.41 \\
Intensive care unit environment & 6 & 16.22 \\
Contact with medical staff & 2 & 5.41 \\
Commuting to the hospital & 5 & 13.51 \\
\hline
\end{tabular}


Table 2. The most frequently endorsed stressful factors in family members of ICU patients in relation to degree of relationship

\begin{tabular}{|c|c|c|c|c|}
\hline \multirow[t]{2}{*}{ The most stressful factors } & \multicolumn{3}{|c|}{ The person hospitalised is my } & \multirow[t]{2}{*}{$P$-value } \\
\hline & $\begin{array}{l}\text { Parent } \\
(N=22)\end{array}$ & $\begin{array}{l}\text { Spouse, partner } \\
\quad(N=10)\end{array}$ & $\begin{array}{l}\text { Others } \\
(N=5)\end{array}$ & \\
\hline Direct threat to the patient's life & $20(90.91 \%)$ & $9(90.00 \%)$ & $4(80.00 \%)$ & 0.767 \\
\hline Poor prognosis & $16(72.73 \%)$ & $5(50.00 \%)$ & $2(40.00 \%)$ & 0.301 \\
\hline $\begin{array}{l}\text { Lack of communication with medical staff and not } \\
\text { providing information about the patient's life }\end{array}$ & $4(18.18 \%)$ & $3(30.00 \%)$ & $0(0.00 \%)$ & 0.507 \\
\hline Altered appearance of the patient & $12(54.55 \%)$ & $7(70.00 \%)$ & $2(40.00 \%)$ & 0.524 \\
\hline $\begin{array}{l}\text { How the family will function after the end } \\
\text { of hospitalisation }\end{array}$ & $7(31.82 \%)$ & $10(100.00 \%)$ & $0(0.00 \%)$ & $<0.001^{*}$ \\
\hline Relationship between family members and medical staff & $3(13.64 \%)$ & $2(20.00 \%)$ & $0(0.00 \%)$ & 0.656 \\
\hline Healthcare bureaucracy & $1(4.55 \%)$ & $0(0.00 \%)$ & $1(20.00 \%)$ & 0.323 \\
\hline Intensive care unit environment & $4(18.18 \%)$ & $2(20.00 \%)$ & $0(0.00 \%)$ & 0.694 \\
\hline Contact with medical staff & $2(9.09 \%)$ & $0(0.00 \%)$ & $0(0.00 \%)$ & 1 \\
\hline Commuting to the hospital & $5(22.73 \%)$ & $0(0.00 \%)$ & $0(0.00 \%)$ & 0.23 \\
\hline
\end{tabular}

$p-\chi^{2}$ test or Fisher's exact test. ${ }^{*}$ Statistically significant relationship $(p<0.05)$.

of the patient), even if the prognosis is unfavourable $(\mathrm{SD}=3.95)$; receiving information on the patient's condition at least once a day $(\mathrm{SD}=3.89)$; receiving instructions from a doctor on how to deal with the patient after leaving the hospital $(\mathrm{SD}=3.89$ ); confidence that the patient is receiving the best possible care (SD $=3.86$ ); and the feeling that there is hope of curing the patient $(\mathrm{SD}=3.78)$. The following issues turned out to be equally important: being informed by the medical staff on the phone about the deterioration of the patient's condition ( $\mathrm{SD}=3.73)$, knowledge of how the patient is treated $(\mathrm{SD}=3.51)$, and including the family in nursing activities ( $\mathrm{SD}=3.41$ ). The following needs were considered the least important: being able to speak with medical staff about the patient's possible death $(\mathrm{SD}=2.92)$; being able to speak with medical staff about their feelings, about what happened (SD = 2.57); and conversation with a hospital chaplain (SD $=2.27)$. All needs included in the study are presented in Table 3.

It was demonstrated that the use of comprehensible language by doctors was a significantly more important need among women $(p=0.036)$. Then, talking to the same doctor every day and feeling that there is hope for curing the patient were more important for people with education other than university education $(p=0.046)$. Being able to talk to medical staff about their feelings and what had happened was, in turn, more important for people who did not live with the patient $(p=0.036)$.

Taking into consideration the specificity of an ICU unit functioning, it was noted that the day of hospitalization significantly $(p<0.05)$ and negatively $(r<0)$ correlated with the assessment of the impor- tance of explaining and describing the unit environment before the first entry into intensive care and the use of comprehensible language by doctors. This means that the longer the hospital stay, the less important these needs $(r=-0.338, p=0.041)$. These values are presented in Table 4.

Values statistically significant were also noted in relation to the place of residence. Talking to the same doctor each day was more important for those commuting 21-50 km than for those commuting over $50 \mathrm{~km}(p=0.04)$, and the possibility of conversation with medical staff about their feelings was more important for those commuting up to $20 \mathrm{~km}$ than for the other respondents $(p=0.013)$. On the other hand, the conversation with the hospital chaplain was more important for people traveling up to $20 \mathrm{~km}$ or over $50 \mathrm{~km}$ than for people living in the place of hospitalization of the patient $(p=0.006)$.

Taking into account the patient's age, it correlates significantly $(p<0.05)$ and negatively $(r<0)$ with the need to obtain truthful and factual information on the patient's condition, even if the prognosis is unfavourable. This means that the older the patient, the less important this need becomes $(r=-0.337, p=0.042)$.

\section{Discussion}

Special conditions at an ICU evoke many negative emotions. Moreover, the equipment monitoring vital functions connected to the patient, the implemented therapeutic procedures, and the patient's changed appearance are extremely stressing. Therefore, it can be assumed that the contact with the medical staff at the unit and the specificity of intensive care are so dif- 
Table 3. Family needs of patients admitted to intensive care units

\begin{tabular}{|c|c|c|c|c|c|c|c|c|c|}
\hline Needs & $N$ & $\begin{array}{l}\text { Missing } \\
\text { data }\end{array}$ & Mean & SD & Median & Min. & Max. & $\mathrm{Q}_{1}$ & $\mathrm{Q}_{3}$ \\
\hline $\begin{array}{l}\text { Information about the patient's condition at } \\
\text { least once a day }\end{array}$ & 37 & 0 & 3.89 & 0.31 & 4 & 3 & 4 & 4 & 4 \\
\hline $\begin{array}{l}\text { An explanation of the ICU environment prior } \\
\text { to first entering }\end{array}$ & 37 & 0 & 3.11 & 0.81 & 3 & 1 & 4 & 3 & 4 \\
\hline Talking to the same physician every day & 37 & 0 & 3.57 & 0.73 & 4 & 1 & 4 & 3 & 4 \\
\hline $\begin{array}{l}\text { Physicians using comprehensible language } \\
\text { (not typical medical) }\end{array}$ & 37 & 0 & 3.27 & 0.73 & 3 & 1 & 4 & 3 & 4 \\
\hline Knowing how the patient is treated & 37 & 0 & 3.51 & 0.65 & 4 & 1 & 4 & 3 & 4 \\
\hline $\begin{array}{l}\text { Being able to speak with medical staff about } \\
\text { feelings, about what happened }\end{array}$ & 37 & 0 & 2.57 & 1.04 & 2 & 1 & 4 & 2 & 3 \\
\hline $\begin{array}{l}\text { Instructions from the physicians about how to } \\
\text { deal with the patient after leaving the hospital }\end{array}$ & 37 & 0 & 3.89 & 0.31 & 4 & 3 & 4 & 4 & 4 \\
\hline The feeling that there is hope for a cure & 37 & 0 & 3.78 & 0.63 & 4 & 1 & 4 & 4 & 4 \\
\hline $\begin{array}{l}\text { Including the family in nursing activities for } \\
\text { the patient }\end{array}$ & 37 & 0 & 3.41 & 0.64 & 3 & 2 & 4 & 3 & 4 \\
\hline $\begin{array}{l}\text { Confidence that the patient is receiving the } \\
\text { best possible care }\end{array}$ & 37 & 0 & 3.86 & 0.42 & 4 & 2 & 4 & 4 & 4 \\
\hline $\begin{array}{l}\text { Being able to speak with medical staff about } \\
\text { the patient's possible death }\end{array}$ & 37 & 0 & 2.92 & 1.09 & 3 & 1 & 4 & 2 & 4 \\
\hline $\begin{array}{l}\text { Being informed by the medical staff on the } \\
\text { phone about the deterioration on the patient's } \\
\text { condition }\end{array}$ & 37 & 0 & 3.73 & 0.61 & 4 & 1 & 4 & 4 & 4 \\
\hline $\begin{array}{l}\text { Being informed by the medical staff about the } \\
\text { improvement of the patient's condition }\end{array}$ & 37 & 0 & 3.7 & 0.74 & 4 & 1 & 4 & 4 & 4 \\
\hline $\begin{array}{l}\text { Truthful information provided by physicians, } \\
\text { even if the prognosis is unfavourable }\end{array}$ & 37 & 0 & 3.95 & 0.23 & 4 & 3 & 4 & 4 & 4 \\
\hline Conversation with the hospital psychologist & 37 & 0 & 3.19 & 0.74 & 3 & 1 & 4 & 3 & 4 \\
\hline Conversation with the hospital chaplain & 37 & 0 & 2.27 & 1.07 & 2 & 1 & 4 & 1 & 3 \\
\hline
\end{tabular}

ficult and overwhelming themselves that, regardless of the patient's health condition, each visit at an ICU is an extremely emotional experience for the relatives. Moreover, the first visit can be such an emotional burden that they do not remember that moment [11].

Therefore, it is extremely important to identify and understand the needs of families of ICU patients and to provide them with both emotional and informational support in this situation. The data obtained clearly showed that for most relatives the key and the most important one was the need for information, especially with regard to providing it truthfully and in accordance with the actual condition of the patient, their prognosis, and receiving instructions on the patient's functioning after the completion of hospitalization. The respondents expressed their willingness to obtain information on the current health condition of a family member at least once a day. The need for certainty that the patient is provided with the best, competent care and that there is hope for their curing was also very intense. These observations are consistent with the data obtained by other authors [5-8].

Therefore, it is an important task of intensive care doctors to provide family members with factual, clear, and compassionate information, which they need in order to cope with their suffering and to participate in making decisions about patients who are unable to communicate with healthcare professionals on their own. However, it is important that the information provided is adjusted to the intellectual abilities of the recipient, without jargon and professional terminology, which is also emphasized by the results of this work. Compared to people with a lower level of education, better educated family members believed more in the importance of talking every day to the same doctor and having hope for the patient's recovery. This may be due to the fact that better educated people find it easier to understand the information 
Table 4. Family needs of patients admitted to intensive care units in relation to the number of days of hospitalisation

\begin{tabular}{|c|c|}
\hline \multirow[t]{2}{*}{ Needs } & Days of hospitalisation \\
\hline & Spearman's correlation coefficient \\
\hline Information about the patient's condition at least once a day & $r=-0.087, p=0.61$ \\
\hline An explanation of the ICU environment prior to first entering & $r=-0.338, p=0.041^{*}$ \\
\hline Talking to the same physician every day & $r=0.283, p=0.09$ \\
\hline Physicians using comprehensible language (not typical medical) & $r=-0.425, p=0.009^{\star}$ \\
\hline Knowing how the patient is treated & $r=0.032, p=0.85$ \\
\hline Being able to speak with medical staff about feelings, about what happened & $r=-0.302, p=0.07$ \\
\hline $\begin{array}{l}\text { Instructions from the physicians about how to deal with the patient after } \\
\text { leaving the hospital }\end{array}$ & $r=-0.285, p=0.087$ \\
\hline The feeling that there is hope for a cure & $r=0.145, p=0.393$ \\
\hline Including the family in nursing activities for the patient & $r=-0.26, p=0.12$ \\
\hline Confidence that the patient is receiving the best possible care & $r=-0.236, p=0.16$ \\
\hline Being able to speak with medical staff about the patient's possible death & $r=-0.186, p=0.269$ \\
\hline $\begin{array}{l}\text { Being informed by the medical staff on the phone about the deterioration on } \\
\text { the patient's condition }\end{array}$ & $r=-0.002, p=0.992$ \\
\hline $\begin{array}{l}\text { Being informed by the medical staff about the improvement of the patient's } \\
\text { condition }\end{array}$ & $r=0.156, p=0.356$ \\
\hline $\begin{array}{l}\text { Truthful information provided by physicians, even if the prognosis is } \\
\text { unfavourable }\end{array}$ & $r=-0.21, p=0.212$ \\
\hline Conversation with the hospital psychologist & $r=-0.186, p=0.269$ \\
\hline Conversation with the hospital chaplain & $r=-0.093, p=0.585$ \\
\hline
\end{tabular}

*Statistically significant relationship $(p<0.05)$

regarding the diagnosis, ICU procedures, and the course of the disease, which may reduce their anxiety level. One should also include considerations for the fact that strong negative emotions may significantly impair the processing of obtained information. The data available in the literature show that only $50 \%$ of ICU patients' families are satisfied with the communication with doctors, and only half of the relatives understand the information provided on diagnosis and treatment, which does not meet the basic standards of informed consent [12]. According to other data, however, it was noted that the stronger feeling of stress was significantly higher among those who believed that the information provided on the subject of the patient's condition was incomplete and insufficient [13]. Proper communication therefore helps the family in coping with the stress related to ICU admission and in adjusting to the new situation [7, 14]. On the other hand, unsatisfied communication and information needs may leave the relatives feeling uninformed, dissatisfied, and deprived of the right to make clinical decisions and care for their loved ones on a daily basis [6].

Some authors [15] suggest that a conversation with the family regarding the patient's condition should begin with the question "What is your understand- ing of the information provided to you by the clinical team?" If the answer differs from the healthcare professionals' point of view, this is the best time to begin identifying discrepancies. In addition to reducing the psychological burden and increasing satisfaction, intensive care units that are able to support interventions based on meeting family information needs also enable each family to provide better support to their relatives at an ICU, thereby increasing the confidence that the patient receives the best care [6]. Involving a psychologist in the work of the unit might also be helpful in this respect. One of the tasks undertaken by a psychologist in the hospital should be participation in the process of communication between the patient's family and the medical staff. The moment of providing information about the patient's condition is difficult and dynamic - each of the participants contributes their currently experienced emotions, temperament, and individual characteristics which may be a source of difficulties in communication. Considering the above, a psychologist should ensure the proper course of the conversation and create the most appropriate conditions for it. The place where the conversation is conducted is also an important element. Holding it in the presence of bystanders, on the run, or in the corridor and without maintaining 
intimacy [12] is disadvantageous. Not only the patient's relatives, but also in the first place the doctors should feel comfortable providing information on the patient's scheduled therapeutic treatment, their current condition, and their prognosis. That would enable the family to ask a wide range of questions, which are aimed at explaining the decisions made and professional terminology [16]. This is difficult because relatives return to the issues discussed already many times, and their perception of the information provided by the doctor is limited. The reason for this may be not only the misunderstanding of the message, but also the fact that, from a psychological point of view, the information that we want to hear is usually accepted first, while the unfavourable information is eliminated from our awareness [12]. In this situation, a safe and secluded place facilitates the acceptance of various, often temperamental reactions of the family. After the conversation is over, a psychologist can go through the information given by the doctors with the family again, once again passing the message in small bits, making frequent summaries, and leaving time for reaction and venting of emotions.

The use of additional forms of communication may also facilitate the communication between the medical personnel and the families of ICU patients. Instructional materials, including educational brochures with pictures describing the nature of the ICU, informing about the environment and equipment at the intensive care unit through leaflets, and advice on interacting with a critically ill person may help families satisfy their information needs [17]. Also, encouraging relatives to ask questions and recognizing their statements may make them feel part of the treatment team [5]. As demonstrated, the ICU patients' families who participated in educational programs had a better understanding of the issues related to the diagnosis and treatment of their relatives. Moreover, those who received informational support were also characterized by a lower level of anxiety, anger, and depression [18].

As reported in the literature, stronger negative emotions during hospitalization of an ICU patient were expressed by women. At the moment of admitting a family member to the unit, in comparison to men, women declared more intense feelings of nervousness, despondency, anxiety, and depression and more intense and persistent stress reactions [19]. This is confirmed by the studies of other authors, who reported that men suppressed anxiety to a greater extent than women [8]. This is somewhat consistent with the results of this study, which showed that in terms of the needs experienced by the participants of the study, women had a higher level of needs in comparison to men. The cause of this difference may be the numerical predominance of women in the study group. However, it can be assumed that women are inherently characterised by being more sensitive, expressing their feelings more openly, and adopting an overly empathetic attitude, which may be crucial when it comes to communication and sharing information by medical staff.

The need for safety was also found to be essential among all the needs listed by the relatives of patients treated at ICUs. This is in line with a number of studies that have reported that the certainty that the patient is receiving the best care reduces the stress of loved ones and contributes to better adaptation to the new situation [20-22].

Involving relatives in the care of patients and their inclusion in simple nursing tasks is also one of the forms of meeting the needs of the families of people treated at ICUs and supporting them. This type of intervention not only allows active participation in the patient's recovery process and acceptance of their limitations but also increases the sense of closeness between the family and the patient and enhances the feeling of being needed [23]. Moreover, it allows for an ongoing registration of changes in the patient. The family then becomes more aware of the situation experienced by them and more aware of the patient's life- and health-threatening condition. Consequently, this may prevent often unrealistic expectations regarding the treatment process [24], but also facilitate contact with medical personnel indirectly modifying family reactions [23]. This may also be of crucial importance in terms of later concerns about the future. In contrast, it has been demonstrated that the altered appearance caused by the disease and the therapeutic management implemented are among the most stressful factors when visiting a loved one. It has also been noted in other authors' works that medical equipment connected to the patient can be equally stressful. The area of the intensive care station contains electrical, vacuum, and oxygen outlets, pumps, suction equipment, monitors, and ventilators. A person surrounded by such a plethora of equipment arouses strong negative emotions in visitors. Nevertheless, family members are eager to participate in caring for patients despite the specificity of ICU functioning and environment. It was noted that up to $87 \%$ of relatives expressed a willingness to participate in the organised care of their loved ones [12]. However, the current survey demonstrated that while this is still an important issue, it is not a priority for everyone. It can be assumed that this stems from the fact that many people do not know how to behave in such a situation and therefore do not feel comfortable participating in the care of critically ill loved ones at ICUs and are afraid of harming them. In such situations, the medical staff can explain how the family can communicate with the patient and explain the principle of stimulating the patient by, for example, talking to them, reading books, touching, or informing them of positive family 
events. Studies have demonstrated that kinship care is associated with better clinical outcomes [16].

Considering the above-mentioned data, the importance of the proper care of the family of a patient treated at an ICU should be emphasized. It includes the reliable and comprehensive provision of information by the medical personnel, development of the communication system, and, after identification of individual expectations, the involvement of the family in simple nursing activities to the extent possible under the conditions of the ICU. Accurate assessment of the needs of the families of patients treated at ICUs and responding to them during the early crisis period is of great importance. It may reduce the negative impact of family stress, enhance the family's ability to interact with and positively support a critically ill relative, influence trust in medical staff, and increase confidence that the patient is receiving the best possible care.

This study has several limitations. First, the small sample size of 37 relatives surveyed limits the representativeness of the results, the statistical power of the analyses obtained, and the extrapolation to a larger population. Consequently, the results should be interpreted with caution. Another limitation of the presented study is also related to the fact that the data verification was carried out over a relatively short period.

The strength of this study lies in its purpose. Few studies are available in Poland on the subject of identifying the needs of the family members of patients treated at intensive care units. Secondly, a 100\% response rate was achieved, with all questionnaires completed in full and no blank responses.

\section{Conclusions}

The most frequently mentioned stressors in the family members of patients treated at ICUs were the following: immediate threat to the patient's life, poor prognosis, altered appearance of the patient, and concerns about how the family will function after the hospitalisation has finished. The following needs were considered to be the most important: provision of truthful information by doctors (with respect to the patient's actual condition) even if the prognosis is not promising, receiving information on the patient's condition at least once a day, receiving guidance from the doctor on how to manage the patient after their discharge from hospital, and confidence that the patient receives the best possible care. The least important need appeared to be the need to have a conversation with the hospital chaplain and being able to talk to the medical staff about their feelings and about what had happened. The spouses/partners of treated patients and those living together with the patient were the most concerned about family functioning after hospitalisation. The use of comprehensible lan- guage by doctors was significantly more important for women. However, the longer the patient stayed at the unit, the less important this need became.

\section{Conflict of interest}

The authors declare no conflict of interest.

\section{References}

1. Bijttebeir P, Vanoost S, Delva D, Ferdinande P, Frans E. Needs of relatives of critical care patients: Perceptions of relatives, physicians and nurses. Intensive Care Med 2001; 27: 160-165.

2. Delva D, Vanoost S, Bijttebeir P, Lauwers P, Wilmer A. Needs and feelings of anxiety of relatives of patients hospitalised in intensive care units: implications for social work. Social Work in Health Care 2015; 35: 21-40.

3. Nelson JE, Kinjo K, Meier DE, Ahmad K, Morrison RS. When critical illness becomes chronic: informational needs of patients and families. J Crit Care 2005; 20: 79-89.

4. Al-Mutair AS, Plummer V, O'Brien A, Clerehan R. Family needs and involvement in the intensive care unit: a literature review. J Clin Nurs 2013; 22: 1805-1817.

5. Scott P, Thomson P, Shepherd A. Families of patients in ICU: a scoping review of their needs and satisfaction with care. Nursing Open 2019; 6: 698-712.

6. Azoulay E, Pochard F, Chevret S, Lemaire F, Mokhtari M, Le Gall JR, Dhainaut JF, Schlemmer B. Meeting the needs of intensive care unit patient families a multicenter study. Am J Respir Crit Care Med 2011; 163: 135-139.

7. Płaszewska-Żywko L, Gazda D. Reakcje emocjonalne i potrzeby rodzin chorych leczonych na oddziale intensywnej terapii. Anestezjol Intens Ter 2012; 44: 164-168.

8. Liew SL, Dharmalingam TK, Ganapathy GK, Muniandy RK, Johnny NGU, Lily NG. Need domains of family members of critically-ill patients: a borneo perspective. Borneo J Med Sci 2018; 12: 27-33.

9. R Core Team (2020). R: A language and environment for statistical computing. R Foundation for Statistical Computing, Vienna, Austria. URL https://www.R-project.org/

10. Białek K, Lickiewicz J. Rola personelu medycznego wobec rodzin pacjentów leczonych na Oddziale Intensywnej Terapii. In: Troska o zdrowie w aspekcie społecznym. Goździalska A, Jaśkiewicz J (eds.). Akademia Frycza Modrzewskiego, Kraków 2015; 43-57.

11. Basińska K, Owczuk R, Suchorzewska J, Wujtewicz M. Komunikacja pomiędzy personelem medycznym a rodzinami chorych leczonych $\mathrm{w}$ oddziale intensywnej terapii - badania wstępne. Anaesth Inten Terap 2011; 43: 85-9.

12. McAdam JL, Puntillo K. Symptoms experienced by family members of patients in intensive care unit. Am J Crit Care 2009; 18: 200-209.

13. Bond E, Draeger CR, Mandleco B, Donnelly M. Needs of family members of patients with severe traumatic brain injury. Crit Care Med 2003; 23: 63-72.

14. Azoulay E, Kentish-Barnes N, Nelson JE. Communication with family caregivers in the intensive care unit: answers and questions. JAMA 2016; 315: 2075-2077.

15. Elliott D, Davidson JE, Harvey M, Bemis-Dougherty A, Hopkins RA. Exploring the scope of post-intensive care syndrome therapy and care: engagement of non-critical 
care providers and survivors in a second stakeholders meeting. Crit Care Med 2014; 42: 2518-2526.

16. Titler M, Bombei C, Schutte D. Developing family-focused care. Crit Care Nurs Clin N Am 1995; 7: 375-387.

17. Halm M. Effects of support groups on anxiety of family members during critical illness. Heart Lung 1990; 19: 62-71.

18. Paparrigopoulos T, Melissaki A, Efthymiou A. Short-term psychological impact on family members of intensive care unit patients. J Psychosom Res 2006; 61: 719-722.

19. Padilla CF. Most important needs of family members of critical patients in light of the Critical Care Family Needs Inventory. Invest Educ Enferm 2014; 32: 306-316.

20. Khatri Chhetri I, Thulung B. Perception of nurses on needs of family members of patient admitted to critical care units of teaching hospital, Chitwan Nepal: a cross-sectional institutional based study. Nurs Res Pract 2018; 2018: 1369164.

21. Shorofi SA, Jannati Y, Moghaddam HR, Yazdani-Charati J. Psychosocial needs of families of intensive care patients: perceptions of nurses and families. Niger Med J 2016; 57: $10-18$.

22. Jezierska N, Borkowski B, Gaszyński W. Psychological reactions in family members of patients hospitalised in intensive care units. Anaesth Intens Terap 2014; 46: 42-45.

23. Suchorzewska J, Basińska K. Rola i znaczenie badania satysfakcji chorych leczonych na oddziałach intensywnej terapii. Anaest Intens Terap 2011; 43: 119-122.

24. Łopacińska I. Pacjent i jego rodzina na oddziale intensywnej opieki medycznej. Probl Pielęg 2009; 17: 50-53.

\section{Address for correspondence:}

\section{Katarzyna Białek}

Institute of Medical Sciences

Faculty of Medicine and Health Sciences

Collegium Medicum

Jan Kochanowski University

Kielce, Poland

Phone: +48512318732

E-mail: katarzynabialek@vp.pl 